\title{
The Exploitation of Expertise: Adjunct Academics and The Commodification of Knowledge
}

\author{
Leanne McRae
}

Henry Giroux wrote in a recent edition of Fast Capitalism that the rise of the adjunct academy in universities is symptomatic of a decline in the democracy of knowledge. He evocatively argues that "protecting critical thought must involve safeguarding the pedagogical and political conditions that make it possible."[1] These conditions include, among others, the validation and respect for knowledge and its evolutionary process into expertise as crucial to the creation of critical citizens and transformative social contexts. The rise of adjunct labour in universities is representative of a widespread disengagement from the higher intentions of pedagogy to cultivate the evolution of expertise or indeed stimulate the formation of knowledge scaffolds as a key prerequisite in free thought and critical interpretive abilities in students. Instead, compliant consumers with knowledge-for-hire, and work-ready graduates, are objectives validated both inside and outside the university. These shifting educational outcomes are not due to the inabilities of adjunct staff to appropriately instruct university students, or to reflexively deploy expertise. They are a result of the contextual conditions that define adjunct labour and that have resulted in the widespread and long-term adoption of sessional work as appropriate employment at universities. Giroux goes on to make clear the consequences of these intersecting educational and employment philosophies and to affirm the corrosion of education for democracy that is being stripped back by decisions to reify an emphasis on processing information, rather than activating knowledge scaffolds that can build expertise.

Unless the attack on academic labor is understood within the larger disciplinary measures at work in university - measures
that aim to eliminate any social formation that can potentially engage in critical pedagogy, challenge authority, and
collectively assume power - the issue of contract labor will appear incidental to the larger transformations and politics now
plaguing higher education. Put differently, higher education needs to be defended as a crucial public sphere, and faculty
autonomy and student empowerment should be regarded as central and powerful components of that vision.[2]

The connections between students and the staff that instruct them - which now is composed almost entirely of adjunct staff at many universities at all levels of their learning - frame and define the manner in which students come into knowledge and develop critical abilities in interpretation and democratic engagement with the social sphere. This interface marks a nexus of competing and cohering ideologies about education, criticism, and work that Giroux argues is reshaping new generations of citizenry in disadvantageous ways.

Giroux's words resonated as I read them. As a member of the adjunct academy for over ten years now, I experience the deep chasm of grief for myself and my students as I move through my daily teaching experiences, informed and overwhelmed by the contexts of educational decision-making and classroom consciousness that are being shaped by neoliberal learning philosophies. This article takes Giroux's warning as a starting point but moves further to unpack adjunct working conditions to define the decline in respect for knowledge and expertise functioning to validate the exploitation of academic labour and the delivery of functional rather than formative learning experiences to students. It also uses the adjunct academy to think through the contemporary intersections between learning, training and democracy that are collapsing and corroding in current educational contexts - springboarding off Giroux's usage 
of Paolo Friere to ponder the relationships between critical pedagogy and the adjunct academy. This article aims to demonstrate how adjuncts work within, for and against these ideas in their daily composition of a living wage and efforts to cultivate a functional and reflexive education for their students. This article argues that adjunct academics currently do extraordinary work when faced with these conditions to both create and interface with the critical needs of students. As a result, adjunct academics embody a nexus through which the conditions of capitalism and current educational outcomes connected to knowledge-as-a-commodity can be visualised, questioned and addressed. By examining the adjunct academy, the wider pedagogic context, characterised by Giroux as a "military-industrialacademic complex"[3] informing the corrosion of critical pedagogy in higher education, can be unpacked and potently positioned within contemporary outcomes for education, social consciousness, democracy and criticism.

The conditions that adjuncts face are only the beginnings of an authentic intervention into the increasing corporatisation of higher education. Understanding how knowledge and expertise is being valued at universities and in the community, is crucial to unpacking the conditions encountered in the classroom at the heart of the knowledge workshop (the university). The stratification of information is being activated for commodification more than for consciousness raising both inside and outside the classroom. This process is embodied and amplified in the adjunct academy where the value of knowledge-for-hire is embraced, encoded on and through the bodies of adjunct staff and implicitly transmitted to students. In order to build on Giroux's call to deepen and widen the critique of the context leading to the increasing employment and exploitation of adjunct labour, I aim to position the adjunct teacher as a crucial site deploying the "performative practice" [4] of pedagogy where the tensions and tenuousness of the shifting meanings around education, training and critical citizenry are mobilised, questioned and confirmed. These scholars/ teachers perform the contradictions interfacing expertise and exploitation currently being normalised in universities.

\section{| Shifting the Knowledge Paradigm}

Social, political and economic attitudes to knowledge have changed with the rise of neoliberal approaches to education, training and learning. These attitudinal shifts percolate inside and outside of the classroom with parents, policy makers, students and staff all mobilising the capital value of contemporary education shaping knowledge as a commodity. Knowledge as it becomes synonymous with training is commodified and exploitable as students seek out education in order to exchange information for a wage. This is a significant shift in consciousness as teachers become facilitators or instructors, and students seek to contain and control knowledge within codified tests, assessment structures and outcomes that are easily measured, acquired and sold. [5] While educators and education systems, have always mobilised knowledge as a commodity - universities are fundamentally about exploring, exchanging and expressing knowledge - the changes to the way in which these skills are valued by the community mark a significant alteration in the way in which education interfaces with democracy. Pedagogy is now increasingly deployed to codify and contain knowledge in easily accessible and transferrable parcels rather than to challenge, explore and transform critical consciousness. In the desire to tap into and tackle the fundamental issue of access to education and democratic learning for diverse groups, which should form the backbone of any educational policy or procedure, the complex processes of thinking, exploring and dialoguing have been masked. These shifts have not gone unnoticed. Martha Nussbaum, for example, challenges the uncritical deployment of neoliberal ideas about education and maps the potential consequences in Not for Profit: Why Democracy needs the Humanities. She argues that democratic education is impoverished if the interests of the national economy outstrip the rights of a critical citizenry. When the curriculum is framed by the national interests, economic growth, motivated by funding distribution decisions at government level, embodied in adjuncts, mobilised by ideologies of 'access' without meaningful understanding of what this is and manifested in rationalised classroom contexts, national economics and the functional skills required for this sector are promoted at the expense of nuanced and considered socially just thought that can intervene in all sectors of the social framework and not just support the wealth and power of elites.

Educators for economic growth will not want a study of history that focuses on injustices of class, caste, gender and ethnoreligious membership, because this will prompt critical thinking about the present. Nor will such educators want any serious consideration of the rise of nationalism, of the damages done by nationalist ideals, and of the way in which the moral imagination too often becomes numbed under the sway of technical mastery ... So the version of history that will be presented will present national ambition, especially ambition for wealth, as a great good, and will downplay issues of poverty and of global accountability.[6] 
The success of neoliberal education ideas means that the students (guided by the attitudes of parents, teachers and university hierarchies about the role and purpose of knowledge and expertise) operate in the spaces where the translation of knowledge into corporate power and capital accumulation fills out instructional contexts. The idea that education might offer critical thought designed to contradict or question the prevailing race to consumerism, big cars and personal communication devices is often met with overt resistance by the student cohort. As Giroux argues this "is not a student who feels a responsibility to others, but one who feels the presence of difference and troubling knowledge as an unbearable burden to be contained or expelled.' [7] The potential for educational transformation is muted as students raised during prosperous times reject the difficulties offered by examining inequality and embrace the seduction of the market as the great equalizer. Capital accumulation solves all problems in this context where the wealthy appear to get away with all manner of illegalities and ethical ambiguities as evidenced in the unfolding global financial crisis where bankers and financiers were largely unaccountable for their decisions that resulted in the collapse of global money markets.[8]

Therefore students demanding value-for-money rarely want the discomfort of a questioning environment or the anxiety of working through an unfamiliar idea. Instead, they want easy concepts, replicated in assignments and traded for passing grades, and functional skills that will serve them in the workplace. They define knowledge as a commodity that can be mapped, measured, bought, sold, tested and traded. Tara Brabazon has aligned these ways of thinking with an uncritical celebration of emergence and deployment of web-based environments in education and the difficulties created when 'googling' replaces research. She argues that "the problem is not Google"[9] but rather "In a fast food, fast data environment, the web transforms into an information drive-through. It encourages a 'type in-download-cut-paste-submit' educational culture." [10] This means that students are rarely processing the information they gather, whether through 'googling' or more sophisticated forms of research, into knowledge by activating and reflecting on the information scaffold provided by curricula. Within this context, "knowledge [is] not only something to create or share, but to exploit."[11] Knowledge is acquired, not processed or struggled over. Students then lack the ability to move into different epistemological hierarchies as they arc through their degrees. Instead of starting with information or data that through assessment and reflection can be processed into knowledge, which then through further and more advanced critical interpretation can become expertise, students are stagnated by abilities and the development of functional skills that conflate data with knowledge. This is why Roksa and Arum discovered in their timely and insightful study into American college campuses that many students are leaving their higher education only marginally better scholars than when they entered college.

students are likely to learn no more in the last two years than they did in the first two, leaving higher education just slightly more proficient in critical thinking, complex reasoning, and writing than when they entered.[12]

They tracked a series of outcomes for students as they moved through their degrees and found significant disparities in students who were not required to engage in coursework involving "critical thinking, complex reasoning, and writing." [13] and those in courses that specified "more than twenty pages of writing [over the entirety of the unit/module and] ... forty pages a reading per week."[14] The students who were not asked to pursue rigorous reading, writing and coursework were less likely to score highly in their abilities to demonstrate knowledge. Roksa and Arum's data points to a widespread shift in the expectations of faculty and students about the composition of higher education, assessment and coursework that defines the cut-and-paste process of contemporary educationas-training. When adjuncts are employed to facilitate the delivery of course material to students, they work in these ambiguous spaces, both as experts and functional labourers communicating course content within the parameters of exchange, but also, when possible, seeking to embody and transmit complex thinking. The conditions they face activate many murky and ambivalent meanings that unmask the problematic protocols of universities dealing with shifting meanings around education, training and learning.

\section{Adjunct Advantages}

More and more adjunct academics are employed at universities and colleges.[15] The amplified rates of causal employment offer a crucible for contemplation where the conditions, outcomes and contexts of the adjunct academy are refracted against the national educational outcomes for students. They appear to be fractured as one set of values and criteria are engaged to recruit potential students (universities as places for the cultivation of knowledge, 
opportunity and expertise), while the educational and employment realities are based on the exploitation of the knowledge and expertise of adjunct staff, often with the assistance of beleaguered and overwhelmed full-time and tenured staff.

There are many different adjunct teachers. Some are highly qualified scholars pasting together full-time employment. Others are postgraduate students paying their way through their higher degrees. Some are semi professionals earning extra money outside of their regular employment. The rationale for employment also varies between institutions. Some have rigorous protocols to ensure their adjuncts are university trained, others are more flexible in their understandings of the transitions between theory and practice, placing more emphasis on 'industry experience'. Some universities are caught short when an overload of students enrol in courses and will employ anyone who is available to be in the classroom. In any case, adjuncts often want to teach well, activate their expertise, and provide transformative experiences for their students. Many are interested in "offering a way of thinking beyond the present, soaring beyond the immediate confines of one's experiences, entering into a critical dialogue with history, and imagining a future that [does] not merely reproduce the present.”[16] However, as a result of their status as knowledge managers straddling the lines between expertise and experience, adjuncts are often silenced by the needs of the university and the conditions of their work. When adjunct teachers are able to fuse the needs of practice with the theories and knowledges that can lead to critical thought and transformative consciousness, they offer a model of radical teaching. This process however, happens in the unclear spaces of teaching and learning and becomes increasingly difficult for adjuncts to mobilise as they become increasingly exploited by the system in which they work. Not only must they struggle against the usual student resistance to difficult thinking, but also through the institutional ambivalence to their success and the codification of their knowledge as expendable and expedient rather than critical and consciousness-raising. As a result of the tenuousness of their employment adjuncts are often working so many jobs that they have been drained of the energy and commitment to inspire their students. It is easier to work through a group exercise than to probe, pursue and provoke their students into difficult thinking. These adjunct conditions demonstrate how knowledge as a socially transformative pursuit is devalued and only reified when it can be used to grow national economies. Knowledge and expertise is exploitable and only valued when monetary rewards are attached, which is why research staff are well paid and at the high end of university promotions tiers and there is often not enough money left over the pay adjunct staff who are downloading data into the student cohort. [17] This does not mean that universities should become places for the lofty navel-gazing investigative idleness of elites. Universities should be spaces for critical and applicable thinking, problem solving and productivity. But when knowledge in exchange for profit is the deepening purpose and profile of universities - whether profits are made from packing more students into classrooms and selling them ideas about exchanging information for money, or from research intensive academic staff bringing in research funding from private and public sources to university budgets, then we impoverish students and the futures of diverse and sustainable national growth. Adjunct academics provide a solution to immediate budget constraints but not to the crisis in learning currently manifesting that mobilises exploitation of knowledge rather than expansion of it. A 'sustainable education' must meaningfully contradict prevailing ideologies attached to this phrase which predominantly indoctrinates educational consumers in an age of excess and radically unsustainable living and working practices. In this context, 'sustainable education' actually means an economically sustainable education that continues to grow the wealth of education providers and the empowered, and not one which supports the creation of radically engaged citizenry that is able to create and convert knowledge into expertise in the assistance of social justice. If teaching and learning is to change in Australia (and elsewhere) and if we are to authentically create 'sustainable' higher education structures, knowledges and outcomes, and societies more generally, then addressing the current callous conditions of university life as both a student and as an academic needs to be carefully and critically addressed.

\section{| Explicit Exploitation}

The litany of unfair and inequitable contexts for adjunct work is staggering. The mismatch between the widely adopted ideologies of the benefits of casualised labour - that adjuncts enjoy greater freedom, flexibility and work/ life balance - and the realities in which sessionals have to hold down multiple jobs across many campuses just to make ends meet, work far more hours than they are paid for, do not have the luxury of sick days or annual leave, have no office space in which to work or meet with students - is startling. The unfair working conditions of the adjunct 
academy are perpetuated at almost all levels of academic work with full-time staff - who are in the unenviable position of having to carry out departmental/university policy - often validating the benefits of adjunct labour, affirming they are 'doing adjuncts a favour' or creating opportunity by offering casual employment. Indeed, adjuncts are often expected to see this offer of work as 'a gift'.[18] This paternalistic attitude is rife in academic departments and is the cancer infecting the employment pool.[19] When full-time and adjunct staff embrace, confirm and perpetuate the neoliberal ideologies that frame the exploitation of casuals as appropriate and desirable, then the war over critically conscious education and the fight for democracy is lost. The exploitation of expertise frames the pursuit of knowledge as functional and not formative. These philosophies are not adopted by all full-time academic staff. But many, in making the best of difficult national educational policy as well as internal funding crises, conform to hierarchical decisions and budgetary constraints determining the shape and tone of their teaching cohort.

Last year I was in a meeting with a senior (tenured) academic who informed me of how wonderful it was for me as a casual academic to have the time to spend exploring research at whim. According to him, I was in a great position to invest my free and flexible time in projects unavailable to full-time academic staff who are often too busy administrating and managing student cohorts as well as juggling their research funding commitments. I sat in silence. I did not mention the fact that I work four jobs and therefore have little time during the week to read course material, let alone conduct detailed research or write papers.[20] On the weeks when assignments are submitted I am often marking two or three classes simultaneously on a two-week turn around, which means I can be marking up to 90 assignments in a week. I did not mention that I am barely paid enough to cover the time spent in preparation and that doing my job well does not guarantee job security.[21] I will be out of contract as soon as the student numbers decline or as a result of the vicissitudes of internal politics and departmental personalities. These realities destroy the myths of casual appointments that encircle a full-time academic's decision making about employment offers. They also point to a series of potentially troubling consequences for the students taught by these overworked employees.

Unfortunately, senior and full-time staff are also victims of these shifting mentalities that perceives adjunct academics as "redundant, superfluous, or entirely disposable."[22] As a result, academic relationships are corroded not only between staff, but between staff and students. Towards the end of the semester I received the following email from the same senior staff member who had advised me of the great benefits of my casual employment.

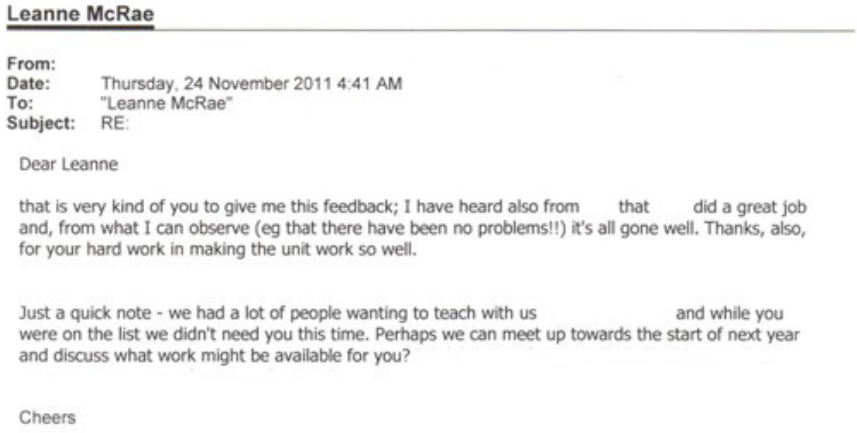

There are many things wrong with this email. Such responses are demoralising. More than that, they are damaging. Upon receiving it I was tempted to ask what precisely I needed in my qualifications and experience to get to the top of his 'list'. [23] But I realised how futile such a response would be having the intuitive knowledge that actually, there is no list. Rather, there are pressures from inside and outside the department that determine employment opportunities along a sliding and unpredictable scale of personal relationships, last minute enrolments, and financial costs and benefits. These pressures are framed by the decreasing critical pedagogic functions of higher education "now re-envisioned from the perspective of a new market-driven form of managerialism"[24] that impoverishes reflexive, critical learning structures in favour of training, skills development, functional literacies and staff that can transmit these skills quickly and effectively.

In a time of economic crisis, global financial collapse and teetering national economies, to be sent this email is 
disturbing at best, negligent at worst. This email speaks to the widening gap between the conditions of full-time and tenured academic staff and those working in the adjunct academy pasting together a full-time job out of a series of part-time opportunities. But at its core this email is a clear demonstration of the conditions adjuncts are faced with in universities and colleges and the impoverishment of pedagogic and instructional knowledge that goes along with the tenuous and fragmented relationships crafted between staff. These attitudes, located both inside and outside the academy, filter down into classrooms where students are modelled pedagogic outcomes based on the exploitation of knowledge and the demobilisation of critical thought.

\section{| Educational Beginnings and Endings}

These attitudinal shifts percolate throughout the learning industries and point to the widespread deprioritisation of a critical and ethical education for contemporary students. Not only must faculty compete with student and parent expectations, but also with increasing pressure on their workloads. The decline in full-time faculty has been met with a comparable increase in the workload for those 'lucky enough' to employed on a full-time basis and as a result, the offloading of teaching intensive work to casual, contract or adjunct labour in universities. This demographic shift in the employment structure within higher education has widespread ramifications for how education is delivered and designed, and most importantly, for how education and knowledge is reflected and refracted through the values of a community. Many of the adjunct staff now delivering higher education to students in university classrooms are highly qualified, motivated and engaged. But the way in which this cohort is contracted, treated, paid and valued by the institutions of education, employment and governance convey serious fallibilities in the current structures of contemporary education and learning as well as the outcomes for a thoughtful, equitable and socially just society.[25]

When we impoverish adjuncts and treat them as disposable add-ons to the more profitable and important research-funded full-time staff we teach students that labour is disposable and that critical thinking is displaced within their everyday lives. We model behaviour that is callous and uncritical. We encourage students to think of their labour as disposable and to replicate ideologies that value success only at the highest levels of academic and intellectual work. They carry this ideology with them into their workplaces and spaces where they enable their own exploitation and the marginalisation of fellow employees. We also enable the dispossession and devaluing of knowledge and expertise. We make the pursuit of profit and the accumulation of education/knowledge for strategic capitalist application more important than reflexive and fair employment for all. We teach these students that their education is only important to the extent that it can be applied within a very narrow definition of productivity and social value.

We no longer live in an economic and attitudinal environment where adjunct instructors can be turned into full-time employees and afforded the same level of benefits and privileges of those staff. But we can re-write the meanings attached to and written on adjuncts bodies. We can use the adjunct as a nexus to peel open the parameters of employment and learning currently being deployed. Rather than lamenting the conditions adjuncts face, we can transform them and ensure that the rigour, intensity and integrity of adjunct instruction is appropriately rewarded both monetarily and through more secure and ratified employment contracts that provide a sense of security within the casualised context. Importantly the processes by which adjunct labour can be valued and transformed to the benefit of higher education, the student cohort and the adjunct themselves must be located in the recognition and value of their diverse and dynamic expertise that is currently being exploited instead of respected and reified. We can resist the stratification of academic staff into 'research' and 'teaching' as if they have nothing to do with each other and better equip students with the literacies to deploy and connect functionality and investigation in their everyday lives enabling them to connect up work, their sense of self, and the meanings they deploy to make sense of these contexts. It is this philosophical shift that must take place first instead of a blanket bolstering of the exaggerated and out-of-touch conditions and experiences adjuncts face both personally and professionally in their role as 'disposable' staff in a learning rich environment.

Adjunct staff commit to, and care passionately about, their students and their education, but they often do not have the time or the energy to compose a classroom of engaged and critically transformative instruction. The fact that many do attempt to achieve these outcomes is testament to their level of organisation and commitment to critical pedagogy. But when we trivialise and exploit this commitment, we teach students that life is mercenary, where only the toughest and most callous survive and thrive - only those at the highest ends of profit making, 
company organisation, education and government enjoy real success and social value. This stratification of thinking removes a grammar of social justice from the social framework and validates 'affluenza' by focussing opportunity through 'luxury fever' where there is "an across-the-board escalation of lifestyle expectations" [26] feeding into and through education where adjuncts are incorrectly coded as having an abundance of 'free and flexible time' and students are increasingly expecting to use knowledge as a commodity to achieve affluent outcomes. This is not to say that the accumulation of wealth is not a viable or desirable outcome of education, but when it is indoctrinated into educational structures implicitly, subtly and overtly it shifts education into a mechanism whereby the widespread exploitation and demoralisation of other global citizens is approved and even normalised. This is a far cry from Michael Apple's and Paolo Freire's worries that education remain connected to and activated by social justice issues if it is to have any meaningful role to play in the crafting of critically conscious futures.

Educational work that is not connected deeply to a powerful understanding of these realities (and this understanding cannot evacuate a serious analysis of political economy and class relations without losing much of its power) is in danger of losing its soul. The lives of our children demand no less.[27]

The role of adjunct staff may be desirable in cutting department budgets and rationalising funding, but their embodiment as archetypes of the exploitative structures of contemporary university philosophies in terms of how their time is valued through payment, job instability, deprioritisation of their research interests and limited access to university hierarchies and opportunities is setting a tone within and through education that our students normalise. These attitudes will be carried with them as they move through the personal and professional lives and the widespread disengagement of education from social justice and philosophical outcomes for a critical citizenry will impoverish nation states. We will, according to Martha Nussbaum "be producing generations of useful machines, rather than complete citizens who can think for themselves, criticize tradition, and understand the significance of another person's sufferings and achievements."'[28] It is important that we engage with the adjunct academy to examine, critique and question the ideologies that normalise the way these scholars/teachers are valued and treated. Through these means we might intervene in the overarching ideologies that frame their employment and how students are engaged, indoctrinated and shaped inside and outside of the classroom. By better valuing adjunct expertise, we might just save our universities, students, staff and citizenry from exploitation, social decline and disempowerment.

\section{Endnotes}

1. H. Giroux, "Rejecting academic labour as a subaltern class: Learning from Paulo Freire and the politics of critical pedagogy," Fast Capitalism, No. 8.2, 2011, http://www.uta.edu/huma/agger/fastcapitalism/8_2/ Giroux8_2.html

2. ibid.

3. ibid.

4. ibid.

5. Jonathan Herman recently noted a shift in what counts as valuable knowledge within universities and schools; "a generation of two ago the very worst thing one could say about a teacher was that he or she went blandly "by the book," assaulted students with facts and figures, and demanded that they "regurgitate" names and dates on tests. It was widely understood that learning should nurture critical thinking, creativity, imagination, analysis and synthesis. But now, many students want "just the facts," and they are often baffled by teachers who seem too lazy or recalcitrant to hand them over, who instead haze them with Socratic method, linger on interminable class discussions, and force them to do research apart from consulting Wikipedia. "Less thinking," they seem to be telling us, "more regurgitation." From Get Schooled with Maureen Downey, "Why don't teacher's just teach what is going to be on the test?" posted 30th April 2012, http://blogs.ajc.com/get-schooled-blog/2012/04/30/ why-don $\% \mathrm{E} 2 \% 80 \% 99 \mathrm{t}$-teachers-just-teach-what-isgoing-to-be-on-the-test $\% \mathrm{E} 2 \% 80 \% 9 \mathrm{D} /$

6. M. C. Nussbaum, Not for Profit: Why democracy needs the humanities, (Princeton: Princeton University Press, 2010), p. 21

\section{Giroux, op cit.}

8. See L. Story and E. Dash, "Bankers reaped bonuses during bailouts," New York Times, http://www. nytimes.com/2009/07/31/business/31 pay.html posted July 30, 2009, and A. Solan, "What's still wrong 
with Wall Street," Time Magazine Business, http://www. time.com/time/magazine/article/0,9171,1933201,00. html posted October 29, 2009,

9. T. Brabazon, The University of Google: Education in the (Post) Information Age, (Aldershot: Ashgate, 2007), p. 23

10. ibid., p. 22

11. ibid., p. 25

12. R. Arum and J. Roksa, Academically adrift: Limited learning on college campuses, (Chicago: University of Chicago Press, 2011), p. 37

13. ibid., p. 71

14. ibid., p. 37

15. Many reports cite the data mapping the increasing numbers of adjunct staff in universities. In Australia, it is estimated "that around 40 per cent of university staff are casual employees. This compares to an average of around 25 per cent in the overall workforce. However, new research using the superannuation records of university staff indicates that there are currently 67 , 00 academics employed on a casual basis, comprising 60 per cent of the academic workforce." E. Bexley, R. James, and S. Arkoudis, The Australian Academic Profession in Transition: Addressing the challenge of reconceptualising academic work and regenerating the academic workforce, Commissioned report prepared for the Department of Education, Employment and Workplace Relations, September 2011, http://www. cshe.unimelb.edu.au/people/bexley_docs/The_ Academic_Profession_in_Transition_Sept2011.pdfp. 1

16. Giroux, op cit.

17. Studies have shown the disparity in pay scales crafted by the concentration of highly paid research staff at universities. "Shifts in the composition of the academic workforce toward the more senior of the classifications also has implications for institutional budgets, as wages at the most senior levels are around twice those of a Level A staff member, reducing the financial base on which to employ more junior staff on an ongoing or long-term basis." Bexley, James, and Arkoudis, op cit., p. 4

18. I. Baranay, "The academic underclass," Griffith Review, No. 11, Getting Smart: The battle for ideas in education, Autumn 2006, p. 41

19. It is also important to note that full-time academic staff experience increased levels of stress as they "must manage the army of sessional staff on top of their work." Bexley, James, and Arkoudis, op cit., p. 1

20. As it happens, this senior academic turned out to be right. The 'free' time I have this semester, as a result of the reduction in sessional hours, was used to write this paper.
21. Different faculties pay adjunct teachers differently. In the last two years payment for marking assignments in Australia has been widely integrated into adjunct pay rates. This initiative is a matter of necessity as adjuncts were increasingly being asked to teach large cohorts and mark their assessments which were taking up significant time chunks of unpaid labour and expertise. The balance of paid tutorial work against unpaid marking work was skewed significantly toward the unpaid apex. Being faced with the widespread disengagement of adjunct staff who were spending their bulk of their out of class time doing work they were not being paid for necessitated the implementation of some form of monetary compensation. However, faculty and university administrators have found ways to circumvent this payment in two key ways that short-change both the adjunct teacher and the students being taught. In humanities departments I have taught in, for example, there are caveats within the marking pay scale. In one university, the pay differs from 'simple' to 'complex' marking varying in rate. Course coordinators are only allowed to claim one assessment component as 'complex' marking for their adjunct staff. Any other assessments must be claimed at the lower 'simple' marking rate. In another humanities department I worked for, course coordinators are only allowed to claim one hour of marking per student at a standardized rate for their adjunct staff. Both these examples result in a short-changing in the education of the students where course coordinators are forced to assess the cohort not based on effective teaching and learning strategies, but by assessments that limit the amount of marking their adjunct lecturers are being paid to complete.

22. Giroux, op cit.

23. I have a Masters Degree, a $\mathrm{PhD}$ and 12 years of teaching experience.

24. Giroux, op cit.

25. This paper has not addressed the potential crisis looming for research within the Australian academy as senior academics begin to age and retire and younger adjunct staff who spend the bulk of their time teaching have not had the time to hone their research skills or developed the publication protocols to continue moving knowledge forward in a proactive and transformative manner.

26. C. Hamilton and R. Denniss, Affluenza: When too much is never enough, (Crow's Nest: Allen and Unwin, 2005), p. 9

27. M. Apple, Cultural politics and education, (New York: Teacher's College, 1996), p. 5

28. Nussbaum, op cit., p. 2 


\section{References}

Apple, M. 1996. Cultural politics and education. New York: Teacher's College.

Arum, R. and Roksa, J. 2011. Academically adrift: Limited learning on college campuses. Chicago: University of Chicago Press.

Baranay, I. "The academic underclass." Griffith Review, No. 11, Getting Smart: The battle for ideas in education. Autumn 2006: $39-49$

Bexley, E. James, R. and Arkoudis, S. 2011. The Australian Academic Profession in Transition: Addressing the challenge of reconceptualising academic work and regenerating the academic workforce, Commissioned report prepared for the Department of Education, Employment and Workplace Relations, September 2011 (http://www.cshe.unimelb.edu.au/people/ bexley_docs/The_Academic_Profession_in_Transition_ Sept2011.pdf)

Brabazon, T. 2007. The University of Google: Education in the (Post) Information Age. Aldershot: Ashgate.

Giroux, H. 2011. "Rejecting academic labour as a subaltern class: Learning from Paulo Freire and the politics of critical pedagogy." Fast Capitalism Vol. 8 No. 2, 2011 (http://www.uta. edu/huma/agger/fastcapitalism/8_2/Giroux8_2.html)
Hamilton, C. and Denniss, R. 2005. Affluenza: When too much is never enough. Crow's Nest: Allen and Unwin.

Herman, J.'Why don't teacher's just teach what is going to be on the test?" Get Schooled with Maureen Downey, posted 30th April 2012 (http://blogs.ajc.com/get-schooledblog/2012/04/30/why-don\%E2\%80\%99t-teachers-just-teachwhat-is-going-to-be-on-the-test $\% \mathrm{E} 2 \% 80 \% 9 \mathrm{D} /$ )

Nussbaum, M. C. 2010. Not for Profit: Why democracy needs the humanities. Princeton: Princeton University Press.

Solan, A. 2009. "What's still wrong with Wall Street." Time Magazine Business online, posted October 29, 2009 (http:// www.time.com/time/magazine/article/0,9171,1933201,00. html)

Story, L. and Dash, E. 2009. "Bankers reaped bonuses during bailouts." New York Times posted July 30, 2009 (http://www. nytimes.com/2009/07/31/business/31 pay.html ) 
